\title{
Cryoconite hole connectivity on the Wright Lower Glacier, McMurdo Dry Valleys, Antarctica
}

\author{
SHELLEY MACDONELL, ${ }^{1,2 *}$ MARTIN SHARP, ${ }^{3}$ SEAN FITZSIMONS ${ }^{2}$ \\ ${ }^{1}$ Centro de Estudios Avanzados en Zonas Áridas (CEAZA), Universidad de La Serena, Campus Andrés Bello, Raúl Bitrán \\ 1305, La Serena, Chile \\ ${ }^{2}$ Department of Geography, University of Otago, PO Box 56, Dunedin, New Zealand \\ ${ }^{3}$ Department of Earth and Atmospheric Sciences, University of Alberta, Edmonton, Alberta T6G 2E3, Canada \\ *Correspondence: Shelley MacDonell <shelley.macdonell@ceaza.cl>
}

\begin{abstract}
Cryoconite holes can be important sources and stores of water and nutrients on cold and polythermal glaciers, and they provide a habitat for various forms of biota. Understanding the hydrological connectivity of cryoconite holes may be the key to understanding the transport of nutrients and biological material to the proglacial areas of such glaciers. This paper aims to characterize and explain spatial variability in the connectivity of ice-lidded cryoconite holes on a small, piedmont glacier in the McMurdo Dry Valleys through geochemical analysis of cryoconite hole waters. Solute concentrations in both surface and near-surface ice and cryoconite holes, vary greatly along the glacier centerline, and all sample types displayed similar spatial patterns of variability. Using chloride as a tracer, we estimated variations in cryoconite hole connectivity along the glacier centerline. We found that a previously used mass transfer method did not provide reliable estimates of the time period for which cryoconite hole waters had been isolated from the atmosphere. We attribute this to spatial variability in both the chloride content of the surface ice and surface ablation rates. The approach may, however, be used to qualitatively characterize spatial variations in the hydrological connectivity of the cryoconite holes. These results also suggest that ice-lidded cryoconite holes are never truly isolated from the nearsurface drainage system.
\end{abstract}

KEYWORDS: cryoconite hole, glacier hydrology, glaciochemistry, supraglacial hydrology

\section{INTRODUCTION}

Drainage or storage of water on glacier surfaces is dictated by the structure of the hydrological network and the temporal variability of hydrological connections. On cold glaciers, cryoconite holes can be important determinants of temporal and spatial patterns of water movement due to their ability to create and store liquid water beneath the ice surface, even where the surface ice is not at the melting point (Wharton and others, 1985; Fountain and others, 2004, 2008; MacDonell and Fitzsimons, 2008).

Cryoconite holes form when differential ablation causes a water-filled depression to form within the surface ice layer. Depending on the air temperature, the developing hole may either stay open to the atmosphere, or may develop an ice cover, thereby 'isolating' the trapped meltwater from external processes. In the latter case, hole formation is likely to accelerate once sediment is incorporated into the ice. This occurs because shortwave radiation can penetrate ice and therefore continues to cause melting at the ice/sediment interface, while longwave emission from the upper surface only cools the ice at the surface and not at depth (Brandt and Warren, 1993; Hoffman and others, 2014). The resulting ablation will cause the hole to grow until it reaches an equilibrium whereby the rate of hole deepening is approximately equal to that of surface lowering around the hole (Gribbon, 1979). Cryoconite hole development is largely restricted to cold-based and polythermal glaciers in high latitude and high-altitude regions (Takeuchi, 2002; Fountain and others, 2004; Anesio and others, 2007), as well as some temperate glaciers (Anesio and others, 2010), where low melt rates generate insufficient runoff to wash sediment from the glacier surface. In arid regions, such as the McMurdo Dry Valleys, cryoconite holes are often ice covered. According to previous studies using changes in chloride mass as a proxy for isolation time, cryoconite holes in Antarctica can remain isolated from both the atmosphere and other holes for several years (Fountain and others, 2004; Bagshaw and others, 2007).

Cryoconite holes have attracted a great deal of attention recently because they are the most biologically active habitat within glacier systems (Säwström and others, 2002; Edwards and others, 2011) and are important nodes for nutrient and hydrological cycling (Irvine-Fynn and others, 2012; Bagshaw and others, 2013). The nutrient and biotic profiles exhibited within cryoconite hole waters are determined by initial ice concentrations and interactions between sediment, microorganisms, water, light and carbon dioxide (Tranter and others, 2004, 2005; Hodson and others, 2008). However, the primary control on differences between holes is likely the local drainage system structure and function (Edwards and others, 2011). Therefore, in order to characterize nutrient cycling and biological productivity on glacier surfaces, an understanding of the hydrological connectivity of cryoconite hole systems is required.

On several glaciers, cryoconite holes have been observed to influence the routing of surface and near-surface meltwater (e.g. Fountain and others, 2004; MacDonell and Fitzsimons, 2008; Cook and others, 2016). Depending on the configuration of the supraglacial drainage system, cryoconite holes can be connected via a variety of processes. 
Firstly, if there is no ice cover on the cryoconite holes, water can flood the cryoconite hole from the surface, and water can evaporate from the hole. Such a situation differs little from standard overland flow processes, as the expectation is that cryoconite holes will then delay water flow in a manner similar to overdeepening in a stream channel. Connections between ice-lidded holes have been thought to occur via fractures within the ice, or via near-surface or surface channels. However, hydrological connectivity via inter-granular drainage within the upper $20 \mathrm{~cm}$ of the ice has been reported (Wakahama and others, 1973; MacDonell and Fitzsimons, 2012; Hoffman and others, 2014; Cook and others, 2016) and this has significant implications for understanding the structure, function and dynamics of supraglacial drainage systems. Depending on the hydrological system structure on a particular glacier, an individual hole may oscillate between being connected and isolated, with connection/isolation times being as long as several years. To date, no studies have monitored water flow directly, but some authors have used variations in chloride concentrations between cryoconite holes to infer patterns of isolation duration (Fountain and others, 2004; Bagshaw and others, 2007).

The aim of this paper is to characterize and explain the spatial variability of connectivity between cryoconite holes and the near-surface drainage system on Wright Lower Glacier, a small piedmont glacier in the McMurdo Dry Valleys, Antarctica. We use the chloride technique to infer variations in cryoconite hole connectivity with elevation along a glacier centerline, and perform a sensitivity analysis of the technique to help evaluate the results. Finally we discuss whether chemical concentration variations do in fact provide a measure of the isolation duration of cryoconite holes, or whether they provide only a relative measure of degree of connectivity.

\section{SITE DESCRIPTION}

The Wright Lower Glacier lies at the western end of the Wright Valley in the McMurdo Dry Valleys $\left(77^{\circ} 25^{\prime} \mathrm{S}\right.$, $\left.162^{\circ} 47^{\prime} \mathrm{E}\right)$, and shares an accumulation area with the Wilson Piedmont Glacier (Fig. 1). Annual precipitation rates at Lake Brownworth (BR-AWS; Fig. 1) are among the lowest recorded in the McMurdo Dry Valleys (Fountain and others, 2010). The mean annual air temperature is $-20^{\circ} \mathrm{C}$ but temperatures can reach $+8^{\circ} \mathrm{C}$ in the summer (Doran and others, 2002). The glacier surface can be divided into two main topographic units. On the true right side of the glacier, the surface is deeply dissected by a series of supraglacial stream channels. The remainder of the glacier surface consists of near-horizontal or slightly undulating terrain (referred to as a planar surface).

On the Wright Lower Glacier, the average percentage area covered by cryoconite holes is 3.5\%, although the distribution is not uniform (Table 1; MacDonell and Fitzsimons, 2008, 2012; MacDonell and others, 2013). As the air temperature is generally below freezing year round, cryoconite holes normally have a near-permanent ice lid that will only disappear during extreme high air temperature events in summer (Foreman and others, 2004). MacDonell and Fitzsimons (2012) showed that cryoconite holes could be hydrologically connected by surface fractures, shallow sub-surface channels, coalescence with other cryoconite holes, and/or intergranular drainage. Spatial patterns of connection modes were not observed. It appeared that connections via cracks and other near-surface channels were largely 'fortuitous', such that a cryoconite hole had to form within a channelized zone to become connected to a channel network. It did not appear that the distribution of cryoconite holes influenced the formation of near-surface channels, as they tended to follow extension cracks. Intergranular drainage was widely observed from early December onwards during repeat mapping of cryoconite holes in a fixed grid as well as during excavation of surface ice across the glacier during December 2005 and January 2007, but the spatial extent and duration of such drainage was not known.

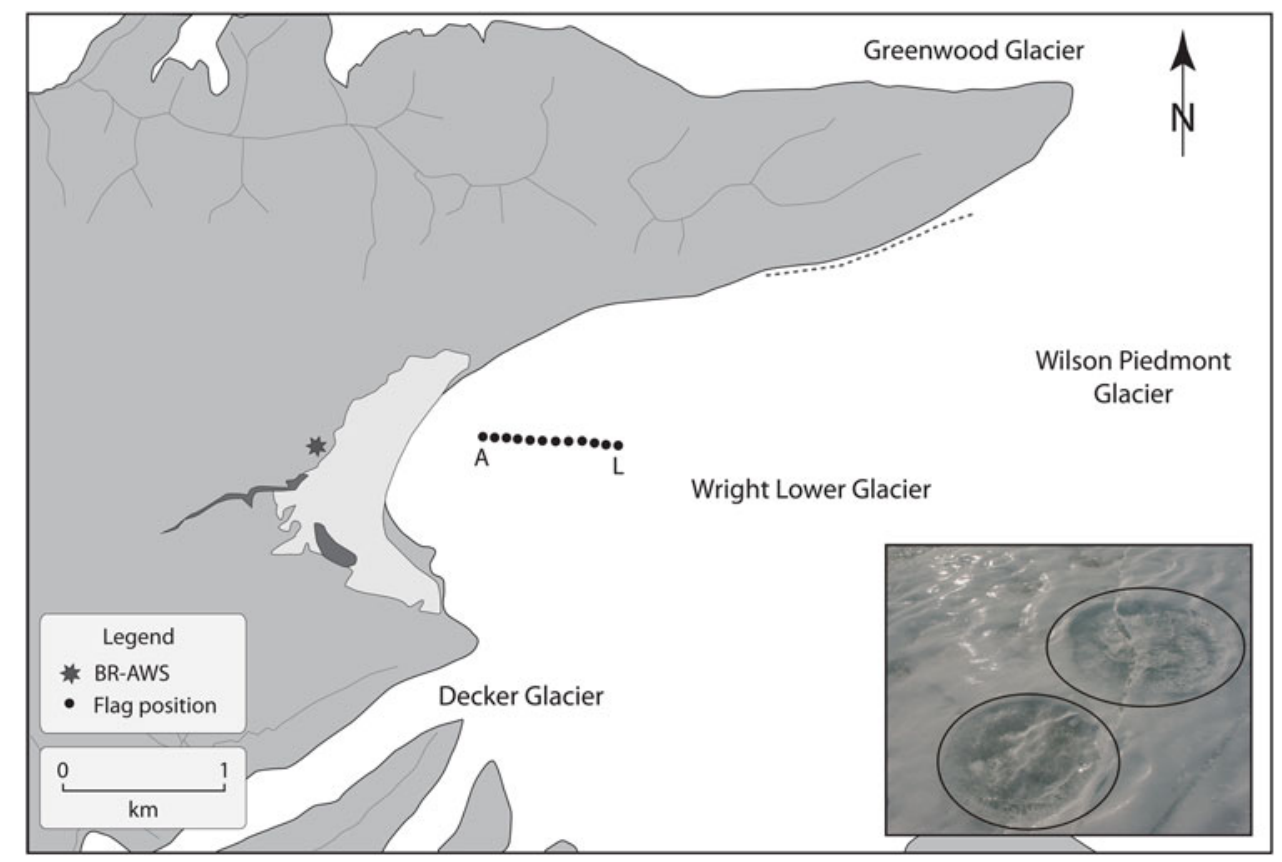

Fig. 1. Map of the Wright Lower Glacier, McMurdo Dry Valleys, Antarctica, show sampling locations. The inset shows two cryoconite holes that are $\sim 45 \mathrm{~cm}$ in diameter. 
Table 1. Areal distribution of cryoconite holes along the glacier centerline (after MacDonell and Fitzsimons, 2012)

\begin{tabular}{|c|c|c|c|c|c|c|c|}
\hline Site & $\begin{array}{l}\text { Measurement area } \\
\mathrm{m}^{2}\end{array}$ & $\begin{array}{l}\text { Distance along centreline }^{\mathrm{a}} \\
\mathrm{m}\end{array}$ & $\begin{array}{l}\text { Elevation } \\
\text { m a.s.l. }\end{array}$ & $\underset{\circ}{\text { Slope }}$ & $\begin{array}{c}\text { Annual ablation rate }{ }^{b} \\
\text { mm w.e. } a^{-1}\end{array}$ & $\begin{array}{c}\text { Area coverage } \\
\%\end{array}$ & Number of holes \\
\hline A & 39 & 0 & 306 & 5 & -184 & 2.2 & 8 \\
\hline B & 17 & 100 & 315 & 3 & -99 & 6.6 & 7 \\
\hline C & 38 & 200 & 321 & 4 & -132 & 3.0 & 12 \\
\hline D & 28 & 300 & 328 & 2 & -172 & 3.5 & 10 \\
\hline E & 56 & 400 & 332 & 2 & -111 & 2.5 & 13 \\
\hline $\mathrm{F}$ & 43 & 500 & 336 & 2 & -81 & 6.3 & 21 \\
\hline G & 32 & 600 & 339 & 2 & -88 & 8.2 & 14 \\
\hline $\mathrm{H}$ & 28 & 700 & 342 & 5 & -85 & 8.6 & 9 \\
\hline I & 50 & 800 & 359 & 2 & -79 & 6.7 & 18 \\
\hline J & 70 & 1000 & 366 & 0 & -71 & 4.9 & 22 \\
\hline
\end{tabular}

\footnotetext{
Distance measured from sampling location A.

b Annual ablation rate of the ice surface between 2004 and 2007.
}

\section{METHODS}

To assess the spatial patterns of hydrological connectivity of cryoconite holes, we used the method employed by Fountain and others (2004) to estimate cryoconite hole isolation at ten sites along the glacier centerline (Fig. 1). This method requires the following input data: (1) chloride concentrations of surrounding ice and cryoconite hole waters, and (2) measurements of hole characteristics such as depth, area and rate of deepening as estimated from local ablation rates (Tables 1 , 2; MacDonell and Fitzsimons, 2012).

Water samples were collected from five cryoconite holes at each of ten locations along the centerline of the glacier on the 29 and 30 December 2005 (locations A-J; Fig. 1), yielding a total of 50 samples. The ten sites were located over a $1 \mathrm{~km}$ distance and sited on average, $100 \mathrm{~m}$ apart. The criteria for selecting the sampled holes were that they (1) were large enough to contain at least $1000 \mathrm{~mL}$ of water and (2) were not visibly connected to near-surface channels. The second condition essentially excluded cryoconite holes positioned in the middle of near-surface channels, as it was difficult to differentiate the boundaries of such holes. At the same locations, five surface ice samples were collected from a 40 to $60 \mathrm{~mm}$ depth adjacent to each ablation stake. This depth was selected to avoid sampling weathered surface ice (Hoffman and others, 2014). The surface ice sampled did not contain either sediment or cryoconite holes. In addition 23 samples were collected at a depth of $750 \mathrm{~mm}$ below the glacier surface at $50 \mathrm{~m}$ intervals between sample locations A-L (Fig. 1). These 'deep ice' samples were taken below the deepest cryoconite hole depth, and so are likely not to have been influenced by surface hydrological processes and associated chemical modifications.

Cryoconite hole water was sampled by drilling a $50 \mathrm{~mm}$ diameter hole through the ice lid using a Kovacs auger and extracting the water with a syringe. Samples were taken from the upper surface of the hole water and it was assumed that the waters were relatively well mixed. Surface ice samples were extracted using a chisel sterilized with ethanol and flamed, and 'deep ice' samples were collected with a Kovacs auger and the outer ice removed using a sterilized and flamed chisel before analysis. All samples were melted and filtered in the field through a 45 $\mu \mathrm{m}$ cellulose nitrate filter paper. Before the samples were filtered, the apparatus was rinsed three times using the sample water before the sample was collected in a $125 \mathrm{~mL}$ Nalgene bottle for solute concentration analysis. After filtering, the samples were frozen. During transportation and storage, the samples were not exposed to temperatures higher than $-18^{\circ} \mathrm{C}$.

In the laboratory, samples were melted and were analyzed within $24 \mathrm{~h}$. When not being used, the samples were sealed to avoid evaporative loss and stored at $4{ }^{\circ} \mathrm{C}$. Chloride $\left(\mathrm{Cl}^{-}\right)$, ammonium $\left(\mathrm{NH}_{4}^{+}\right)$, nitrate $\left(\mathrm{NO}_{3}^{-}\right)$and phosphate $\left(\mathrm{PO}_{4}^{2-}\right)$ concentrations were analyzed using a Foss FIAStar 5000 Flow Injection Analyzer; concentrations of sodium $\left(\mathrm{Na}^{+}\right)$, magnesium $\left(\mathrm{Mg}^{2+}\right)$, potassium $\left(\mathrm{K}^{+}\right)$and calcium $\left(\mathrm{Ca}^{2+}\right)$ were determined using a Varian Spectra 240FS Atomic Absorption Spectrometer. Repeat samples were analyzed for each analyte, and a blank sample (class 1 water) and standard of known concentration were analyzed every 15 samples. The blank sample and standard results were used to assess the errors associated with the solute concentration analysis (Table 3). At the time of analysis it was not possible to measure $\mathrm{SO}_{4}^{2-}$ and $\mathrm{HCO}_{3}^{-}$concentrations, so these have been estimated for each sample from the total charge balance errors (CBE).

Chloride concentrations were used to estimate the length of cryoconite hole isolation. Fountain and others (2004) suggested that the duration of hole isolation could be calculated from the difference between the measured concentrations of a non-reactive, non-biologically utilized solute, such as $\mathrm{Cl}^{-}$ (Gooseff and others, 2004) and the surrounding glacier ice concentration. Chloride is a useful marker in this environment because it is irreversibly deposited within snowpacks (Cragin and McGilvary, 1995), and is highly soluble. The dominant source of $\mathrm{Cl}^{-}$in the lower valley system is the Ross Sea, however a very small contribution from the valley floor cannot be eliminated (Witherow and others, 2006). The contribution from lithic sources is likely to be insignificant, and we assume the amount of sediment contained within the hole should not affect the $\mathrm{Cl}^{-}$concentration or mass (Fountain and others, 2004). Therefore, $\mathrm{Cl}^{-}$mass will only fluctuate due to inputs from ice/snow melt or the effects of freeze-concentration. Fountain and others (2004) suggested using $\mathrm{Cl}^{-}$concentrations to calculate the length of hydrological isolation (in years) using:

$$
\Delta t=\left(\frac{M(t)}{a \times i}-h\right)\left(\frac{d z}{d t}\right)^{-1}
$$

where: $M(t)$ is the mass of $\mathrm{Cl}^{-}(\mu \mathrm{mol})$ at a particular time $t(\mathrm{a})$; a is the cross-sectional area of the hole $\left(\mathrm{m}^{2}\right) ; i$ is the average 
Table 2. Mean cryoconite hole physical properties at each of the surveyed locations along the glacier centerline (Fig. 1)

\begin{tabular}{|c|c|c|c|c|c|c|c|c|}
\hline Site & $\begin{array}{l}\text { Elevation } \\
\text { m a.s.l. }\end{array}$ & $\begin{array}{l}\text { Diameter } \\
\mathrm{mm}\end{array}$ & $\begin{array}{l}\text { Water depth } \\
\text { mm }\end{array}$ & $\begin{array}{c}\text { Head space } \\
\text { Mm }\end{array}$ & $\begin{array}{l}\text { Ice thickness } \\
\mathrm{mm}\end{array}$ & $\begin{array}{l}\text { Total depth } \\
\mathrm{mm}\end{array}$ & $\begin{array}{c}\text { Water volume } \\
\mathrm{m}^{3}\end{array}$ & $\begin{array}{c}\text { Maximum volume }{ }^{b} \\
\mathrm{~m}^{3}\end{array}$ \\
\hline A & 306 & 385 & 161 & 5 & 176 & 342 & 0.021 & 0.022 \\
\hline B & 315 & 503 & 146 & 21 & 169 & 336 & 0.036 & 0.038 \\
\hline C & 321 & 429 & 168 & 6 & 255 & 429 & 0.026 & 0.026 \\
\hline D & 328 & 416 & 165 & 9 & 212 & 386 & 0.023 & 0.025 \\
\hline $\mathrm{E}$ & 332 & 475 & 175 & 41 & 192 & 408 & 0.031 & 0.040 \\
\hline G & 339 & 644 & 160 & 10 & 142 & 312 & 0.056 & 0.058 \\
\hline $\mathrm{H}$ & 342 & 468 & 74 & 87 & 121 & 282 & 0.016 & 0.039 \\
\hline I & 359 & 653 & 156 & 23 & 131 & 310 & 0.050 & 0.060 \\
\hline$J$ & 366 & 623 & 155 & 56 & 57 & 268 & 0.057 & 0.066 \\
\hline
\end{tabular}

Measured properties at each site included water depth, head space (i.e. the air space between water and the ice lid in the hole), ice thickness and total depth. Mean values were calculated from the five holes surveyed at each site. The average diameter value given was calculated by averaging the diameter in the northsouth direction with that measured in the east-west direction (after MacDonell and Fitzsimons, 2012).

a Water volume corresponds to the volume of water in the hole at the time of measurement.

b Maximum volume corresponds to the maximum space available to hold water (i.e. the combination of head space and current water depth).

concentration of $\mathrm{Cl}^{-}\left(\mu \mathrm{mol} \mathrm{m}{ }^{-3}\right)$ in the surrounding ice, which is assumed to be constant in space and time; $h$ is the depth of the hole $(\mathrm{m})$; and $d z / d t$ is the melt rate at the base of the hole, which is assumed to be equal to the ablation rate of the ice surface. Fountain and others (2004) argued that if Eqn (1) yields a value $>0$, then that value represents the number of years for which the hole has been hydrologically isolated. Conversely, if it yields a value $<0$, the implication is that the cryoconite hole is hydrologically connected.

\section{MAJOR ION CONCENTRATIONS IN CRYOCONITE HOLES AND SURFACE ICE}

\subsection{Major ions in ice}

Major ion concentrations were evaluated in surface and near-surface (750 $\mathrm{mm}$ depth) ice to determine baseline glaciochemical signatures that would inform the analysis of cryoconite hole waters (Tables 4, 5). The dominant major ions in the surface ice samples were $\mathrm{Na}^{+}$and $\mathrm{Cl}^{-}$, followed by $\mathrm{Ca}^{2+}$ and $\mathrm{K}^{+}$(Table 4). The dominant major ions are similar to those reported in other areas of the McMurdo Dry Valleys (Lyons and others, 2003; Tranter and others,

Table 3. Summary table for the precision, accuracy and detection limit of solute analyses (unless otherwise stated, values are given as $\mu \mathrm{eq} \mathrm{L}^{-1}$ )

\begin{tabular}{lccc}
\hline Solute & Precision $^{\mathrm{a}}$ & Accuracy $^{\mathrm{b}}$ & Detection limit $^{\mathrm{c}}$ \\
\hline $\mathrm{Na}^{+}$ & 8 & 3 & 25 \\
$\mathrm{Mg}^{2+}$ & 3 & 1 & 9 \\
$\mathrm{~K}^{+}$ & 6 & 2 & 17 \\
$\mathrm{Ca}^{2+}$ & 13 & 4 & 41 \\
$\mathrm{Cl}^{-}$ & 1 & 2 & 4 \\
$\mathrm{NH}_{4}^{+}$ & 3 & 2 & 9 \\
$\mathrm{NO}_{3}^{2-}$ & 1 & 0 & 0 \\
$\mathrm{PO}_{4}^{2-}$ & 1 & 0 & 4
\end{tabular}

Values were calculated as outlined in Fitzsimons and others (2008).

a Precision was calculated as the standard deviation of repeated assays of blank standards.

b Accuracy was calculated as the mean of the differences between the measured and expected concentration.

c Detection limit was calculated as the standard deviation of repeated assays of blank samples multiplied by three.
2004, 2005), however the concentrations are lower, and the prominence of $\mathrm{Ca}^{2+}$ is reduced. As seen throughout the McMurdo Dry Valleys, it is likely that $\mathrm{Na}^{+}$and $\mathrm{Cl}^{-}$are of predominantly marine origin as the main source of precipitation is from the Ross Sea (Fountain and others, 2010). The relative concentrations of the other major ions $\left(\mathrm{Ca}^{2+}, \mathrm{K}^{+}\right)$are likely to be influenced greatly by local lithological sources (Lyons and others, 2003) and biological activity. The CBE suggest there are also small amounts of $\mathrm{HCO}_{3}^{-}$and $\mathrm{SO}_{4}^{2-}$ in the samples, accounting for $\sim 32 \%$ of the anion load. In order to better understand the $\mathrm{CBE}$ composition, $\mathrm{SO}_{4}^{2-}$ concentrations were estimated using the marine $\mathrm{SO}_{4}^{2-}: \mathrm{Cl}^{-}$ratio of 0.14 (Kroopnick, 1977), and $\mathrm{HCO}_{3}^{-}$was estimated from the remaining $\mathrm{CBE}$. This suggests that nonanalysis of $\mathrm{HCO}_{3}^{-}$ accounts for the largest fraction of the $\mathrm{CBE}$, which is approximately equal to $\mathrm{Ca}^{2+}+\mathrm{Mg}^{2+}$, likely due to the production of $\mathrm{Ca}^{2+}, \mathrm{Mg}^{2+}$ and $\mathrm{HCO}_{3}^{-}$by calcium carbonate weathering (Fortner and others, 2005). This pattern held for surface ice and deep ice samples at most locations, but differences were observed at sites $E$ and $F$ for both surface and deep ice samples, and at site D for surface ice, and site $G$ in deep ice (Tables 4, 5). At these sites, CBE was lower and $\mathrm{SO}_{4}^{2-}$ values were slightly elevated, which suggests that there may be slightly elevated rates of silicate weathering occurring within these regions (Fortner and others, 2005).

In surface ice samples, the mean $\mathrm{Cl}^{-}: \mathrm{Na}^{+}$ratio is $1.26 \pm$ 0.08 , slightly greater than the sea-water ratio of 1.16 (Keene and others, 1986) and also greater than the deep ice ratio of $1.16 \pm 0.14$, suggesting that the ratio may have been modified post-deposition. The high ratio is not uncommon throughout the McMurdo Dry Valleys. For example, Lyons and others (2003) report high ratios for the Commonwealth (1.20-1.37), Howard (1.13-1.54) and Newall (1.72) glaciers, and Tranter and others (2005) and Bagshaw and others (2007) report negative values for $\mathrm{Na}^{+}$once corrected for sea salt. Both Lyons and others (2003) and Tranter and others (2005) suggest there may be another source of $\mathrm{Cl}^{-}$ in the region, such as volcanic gases or a far-travelled aerosol from the stratosphere to which $\mathrm{HCl}^{-}$has been added. It is also possible that the relative abundance of $\mathrm{Cl}^{-}$ could be due to the incorporation of frost flowers blown in from nearby sea ice (Wolff and others, 2003; Domine and others, 2004) or from sublimation enhancement (Lyons and others, 2003). Frost flowers develop on the surface of thin 
Table 4. Mean solute concentrations in surface ice samples along the glacier centerline $\left(\mu \mathrm{eq} \mathrm{L}^{-1}\right.$ )

\begin{tabular}{|c|c|c|c|c|c|c|c|c|c|c|c|c|c|}
\hline Site & $n$ & $\Sigma^{+}$ & $\mathrm{K}^{+}$ & $\mathrm{Na}^{+}$ & $\mathrm{Ca}^{2+}$ & $\mathrm{Mg}^{2+}$ & $\mathrm{NH}_{4}^{+}$ & $\Sigma^{-}$ & $\mathrm{NO}_{3}^{-}$ & $\mathrm{PO}_{4}^{-}$ & $\mathrm{Cl}^{-}$ & $\mathrm{SO}_{4}^{2-}$ & $\mathrm{HCO}_{3}^{-}$ \\
\hline A & 5 & 16 & 2 & 9 & 1 & 1 & 3 & 11 & 1 & 0 & 10 & 1 & 4 \\
\hline B & 5 & 27 & 5 & 11 & 6 & 1 & 4 & 20 & 1 & 5 & 14 & 2 & 5 \\
\hline C & 5 & 21 & 6 & 8 & 2 & 1 & 4 & 16 & 1 & 4 & 11 & 2 & 3 \\
\hline D & 5 & 20 & 5 & 9 & 3 & 1 & 2 & 19 & 1 & 6 & 12 & 2 & 0 \\
\hline$E$ & 5 & 20 & 4 & 10 & 4 & 1 & 1 & 18 & 1 & 4 & 13 & 2 & 0 \\
\hline $\mathrm{F}$ & 5 & 48 & 7 & 25 & 9 & 5 & 2 & 41 & 1 & 9 & 31 & 4 & 3 \\
\hline $\mathrm{H}$ & 5 & 39 & 6 & 21 & 7 & 3 & 2 & 26 & 1 & 0 & 25 & 4 & 10 \\
\hline I & 5 & 24 & 4 & 12 & 5 & 2 & 1 & 21 & 1 & 4 & 16 & 2 & 1 \\
\hline$J$ & 5 & 40 & 9 & 25 & 3 & 2 & 1 & 30 & 1 & 0 & 29 & 4 & 6 \\
\hline Mean & 50 & 29 & 5 & 15 & 5 & 2 & 2 & 24 & 1 & 4 & 19 & & \\
\hline Standard deviation & 50 & 15 & 2 & 7 & 3 & 1 & 2 & 17 & 0 & 8 & 9 & & \\
\hline
\end{tabular}

$\mathrm{NB}: \mathrm{HCO}_{3}^{-}+\mathrm{SO}_{4}^{2-}=5$.

sections of sea ice and their $\mathrm{Cl}^{-}$concentrations are higher than those of sea ice brines and sea water (Douglas and others, 2012). Frost flowers are readily removed from sea ice surfaces, and in conjunction with other processes can alter the chemistry of local air masses (Domine and others, 2004). Once these air masses are forced onshore, aerosols contained within them can be deposited. As $\mathrm{Cl}^{-}$is irreversibly deposited in snow and ice, it will not evaporate or sublimate from the surface unless the feature is removed. Therefore, sublimation, which is the prevalent ablation process on the surface of the Wright Lower Glacier (MacDonell and others, 2013), should result in further enrichment of immobile chemical species such as $\mathrm{Cl}^{-}$at the surface (Ginot and others, 2001).

Solute concentrations vary spatially along the glacier centerline (Fig. 2; Table 4). Figure 2 and Table 4 show that the concentration of $\mathrm{Cl}^{-}$in the surface ice varies across the glacier surface. Essentially, surface ice closer to the terminus has a lower $\mathrm{Cl}^{-}$concentration (at a given depth) than ice further from the terminus, but the variation with distance is not linear. Between sites A and E, mean chloride concentration varies between 10 and $14 \mu \mathrm{eq} \mathrm{L}{ }^{-1}$, whereas between $\mathrm{F}$ and $\mathrm{J}$ the mean concentrations lie between 16 and $31 \mu \mathrm{eq}$ $L^{-1}$. There is a step change between sites $E$ and $F(13-31$ $\mu e q L^{-1}$, respectively), which coincides with a marked decrease in surface ablation rates $\left(111-81 \mathrm{~mm}\right.$ w.e. $\mathrm{a}^{-1}$, respectively). While it is possible that $\mathrm{Cl}^{-}$concentrations vary with distance from the source, in this case the Ross Sea, this effect is likely to explain only a small percentage of the variation over the $1 \mathrm{~km}$ length of the study transect. The implication may be that higher melt rates near the terminus result in enhanced flushing of $\mathrm{Cl}^{-}$from the surface ice. Therefore, any analysis of residence times using a $\mathrm{Cl}^{-}$ signature should take into consideration the underlying spatial signature seen in both surface and deep ice samples.

\subsection{Cryoconite hole water chemistry}

Analysis of the cryoconite hole water chemistry along the glacier centerline shows that $\mathrm{Cl}^{-}, \mathrm{Ca}^{2+}, \mathrm{Na}^{+}$and $\mathrm{Mg}^{2+}$ are the dominant ions and that concentrations of $\mathrm{Cl}^{-}, \mathrm{Ca}^{2+}$ and $\mathrm{Mg}^{2+}$ are up to an order of magnitude higher than in clean glacier ice (Tables 4-6). The cryoconite hole water is also enriched in $\mathrm{NO}_{3}^{-}$and depleted in $\mathrm{NH}_{4}^{+}$compared with surface ice, however values of both species are very close to the detection limits. The mean CBE $\left(69 \mu \mathrm{eq} \mathrm{L}^{-1}\right)$ is larger in cryoconite hole samples than in the surface and deep ice samples, which suggests that concentrations of $\mathrm{HCO}_{3}^{-}$ and/or $\mathrm{SO}_{4}^{2-}$ are much higher in the cryoconite hole samples than in the ice samples. This may indicate that there is a larger contribution from weathering to the cryoconite hole waters. As $\mathrm{Ca}^{2+}+\mathrm{Mg}^{2+}$ is almost always higher than the $\mathrm{CBE}$ in cryoconite hole samples, $\mathrm{HCO}_{3}^{-}$is likely not fully balancing $\mathrm{Ca}^{2+}+\mathrm{Mg}^{2+}$. As the $\mathrm{SO}_{4}^{2-}$ amount

Table 5. Mean solute concentrations in deep ice samples along the glacier centerline ( $\mu$ eq $\mathrm{L}^{-1}$ )

\begin{tabular}{|c|c|c|c|c|c|c|c|c|c|c|c|c|c|}
\hline Site & $n$ & $\Sigma^{+}$ & $\mathrm{K}^{+}$ & $\mathrm{Na}^{+}$ & $\mathrm{Ca}^{2+}$ & $\mathrm{Mg}^{2+}$ & $\mathrm{NH}_{4}^{+}$ & $\Sigma^{-}$ & $\mathrm{NO}_{3}^{-}$ & $\mathrm{PO}_{4}^{-}$ & $\mathrm{Cl}^{-}$ & $\mathrm{SO}_{4}^{2-}$ & $\mathrm{HCO}_{3}^{-}$ \\
\hline A & 2 & 53 & 13 & 26 & 9 & 5 & 0 & 32 & 2 & 1 & 29 & 4 & 17 \\
\hline B & 3 & 22 & 2 & 8 & 9 & 3 & 0 & 12 & 1 & 0 & 11 & 2 & 8 \\
\hline C & 3 & 18 & 2 & 7 & 7 & 2 & 0 & 10 & 1 & 0 & 9 & 1 & 7 \\
\hline D & 3 & 15 & 2 & 10 & 2 & 1 & 0 & 10 & 1 & 0 & 9 & 1 & 4 \\
\hline $\mathrm{E}$ & 3 & 24 & 4 & 15 & 2 & 3 & 0 & 20 & 2 & 0 & 18 & 3 & 1 \\
\hline $\mathrm{F}$ & 3 & 44 & 5 & 26 & 8 & 5 & 0 & 36 & 2 & 0 & 34 & 5 & 3 \\
\hline $\mathrm{H}$ & 3 & 44 & 4 & 19 & 18 & 3 & 0 & 25 & 2 & 0 & 23 & 3 & 16 \\
\hline I & 3 & 46 & 5 & 21 & 16 & 4 & 0 & 23 & 1 & 0 & 22 & 3 & 20 \\
\hline $\mathrm{J}$ & 3 & 25 & 4 & 15 & 1 & 5 & 0 & 17 & 2 & 0 & 15 & 2 & 6 \\
\hline K & 3 & 24 & 3 & 16 & 0 & 5 & 0 & 18 & 1 & 0 & 17 & 2 & 4 \\
\hline $\mathrm{L}$ & 2 & 27 & 4 & 16 & 0 & 7 & 0 & 19 & 1 & 0 & 18 & 3 & 5 \\
\hline Mean & 23 & 31 & 4 & 17 & 6 & 4 & 0 & 21 & 2 & 0 & 19 & & \\
\hline Standard deviation & 23 & 29 & 4 & 12 & 11 & 2 & 0 & 15 & 1 & 0 & 14 & & \\
\hline
\end{tabular}

$\mathrm{NB}: \mathrm{HCO}_{3}^{-}+\mathrm{SO}_{4}^{2-}=10$. 


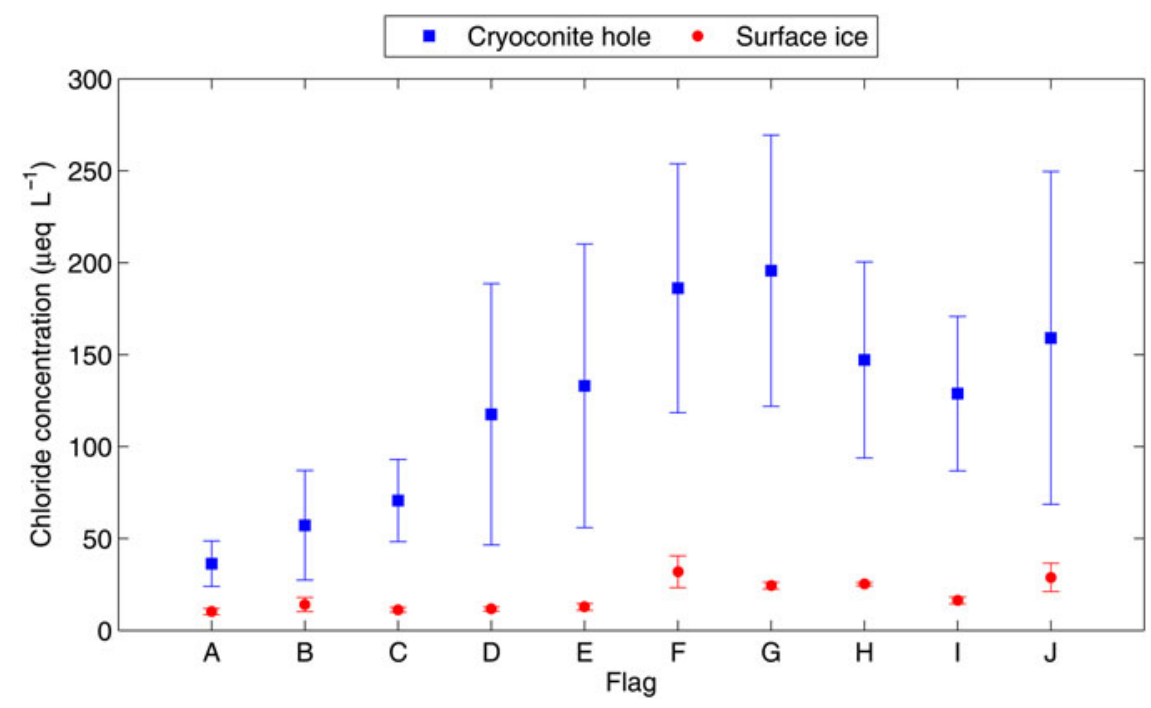

Fig. 2. Mean values of chloride concentrations in surface ice and cryoconite hole water at sites A-J along the glacier centerline.

derived from seawater does not account for the difference, it is likely there is an additional source of $\mathrm{SO}_{4}^{2-}$, such as soils from the valley floor (Lyons and others, 2003). However, as $\mathrm{SO}_{4}^{2-}$ was not measured this cannot be confirmed.

Table 7 shows the results of a series of two-tailed Pearson correlation analyses relating the concentrations of $\mathrm{Na}^{+}$, $\mathrm{Ca}^{2+}, \mathrm{Mg}^{2+}$ and $\mathrm{Cl}^{-}$to cryoconite hole and site properties. Distance from the terminus and annual ablation rate provided the strongest controls over solute concentrations, indicating that concentrations increased up-glacier and with decreasing ablation rate (for all variables, $r$ is significantly different from zero at $>99 \%$; Table 7 ). As ablation rate, distance from the terminus, elevation and surface slope all vary spatially together, it is not surprising that they relate to solute concentrations in similar ways. Cryoconite hole depth is the only physical property of cryoconite holes that is correlated concentrations of all solute species. These results suggest that site properties play a more important role in determining cryoconite hole chemistry than individual hole characteristics.

When the concentrations of each solute for each sample type (i.e. surface ice, deep ice and cryoconite hole water) were compared with sample locations, it was found that for all sample types: $\mathrm{Cl}^{-}$had a distinctive peak at site $\mathrm{G} ; \mathrm{Na}^{+}$ and $\mathrm{Mg}^{2+}$ peaked at sites $\mathrm{F}$ and $\mathrm{G}$ and $\mathrm{Ca}^{2+}$ was relatively high between sites $\mathrm{F}$ and I (Tables 4-6). For the cryoconite holes, the high concentrations of solutes between sites $\mathrm{F}$ and I are probably related to weathering of sediment as the charge imbalances are highest at these locations. However $\mathrm{Cl}^{-}$also peaks in this location. These sites have the highest cryoconite hole cover (Table 1), which is most probably related to sediment accumulation in this area of the glacier (Fountain and others, 2004). Here cryoconite holes cover $6-8 \%$ of the glacier surface, which is twice the average (Table 1). The reasons for greater sediment accumulations in this region are currently unknown. It is possible that there is a maximum possible distance for sediment transport by westerly winds, or that at lower elevations more sediment has been removed by water flow. In addition, there is an abrupt up-glacier decrease in ablation rate between sites $E$ and $\mathrm{F}$, and so it is likely that there is less meltwater available to wash sediment from the surface, enabling cryoconite hole development (MacDonell and others, 2013).

\section{CRYOCONITE HOLE CONNECTIVITY}

\subsection{Model results}

In order to assess the ratio of stored to transported water, an understanding of potential and real cryoconite hole connectivity is required. As a first attempt at understanding connectivity between holes, the 'cryoconite hole isolation

Table 6. Mean solute concentrations in cryoconite hole samples along the glacier centerline $\left(\mu \mathrm{eq} \mathrm{L}{ }^{-1}\right.$ )

\begin{tabular}{|c|c|c|c|c|c|c|c|c|c|c|c|c|c|}
\hline Site & $n$ & $\Sigma^{+}$ & $\mathrm{K}^{+}$ & $\mathrm{Na}^{+}$ & $\mathrm{Ca}^{2+}$ & $\mathrm{Mg}^{2+}$ & $\mathrm{NH}_{4}^{+}$ & $\Sigma^{-}$ & $\mathrm{NO}_{3}^{-}$ & $\mathrm{PO}_{4}^{-}$ & $\mathrm{Cl}^{-}$ & $\mathrm{SO}_{4}^{2-}$ & $\mathrm{HCO}_{3}^{-}$ \\
\hline A & 5 & 78 & 6 & 28 & 28 & 15 & 1 & 37 & 1 & 0 & 36 & 5 & 36 \\
\hline B & 5 & 127 & 6 & 40 & 56 & 24 & 1 & 65 & 7 & 1 & 57 & 8 & 54 \\
\hline C & 5 & 141 & 10 & 42 & 58 & 29 & 2 & 77 & 6 & 0 & 71 & 10 & 54 \\
\hline $\mathrm{D}$ & 5 & 197 & 14 & 64 & 79 & 40 & 0 & 129 & 5 & 6 & 118 & 17 & 51 \\
\hline $\mathrm{E}$ & 5 & 207 & 13 & 75 & 78 & 41 & 0 & 138 & 5 & 0 & 133 & 19 & 50 \\
\hline $\mathrm{F}$ & 5 & 292 & 14 & 94 & 121 & 63 & 0 & 199 & 13 & 0 & 186 & 26 & 67 \\
\hline G & 5 & 296 & 14 & 95 & 124 & 63 & 0 & 214 & 18 & 0 & 196 & 27 & 55 \\
\hline $\mathrm{H}$ & 5 & 268 & 13 & 72 & 123 & 60 & 0 & 160 & 13 & 0 & 147 & 21 & 87 \\
\hline I & 5 & 242 & 12 & 71 & 107 & 52 & 0 & 144 & 15 & 0 & 129 & 18 & 80 \\
\hline J & 5 & 169 & 14 & 66 & 62 & 27 & 0 & 168 & 9 & 0 & 159 & 22 & 0 \\
\hline Mean & 50 & 202 & 12 & 65 & 84 & 41 & 0 & 133 & 9 & 1 & 123 & & \\
\hline Standard deviation & 50 & 102 & 5 & 28 & 45 & 23 & 1 & 85 & 7 & 4 & 74 & & \\
\hline
\end{tabular}

$\mathrm{NB}: \mathrm{HCO}_{3}^{-}+\mathrm{SO}_{4}^{2-}=69$. 
Table 7. Two-tailed Pearson correlation coefficient results of comparison between cryoconite hole solute concentrations and site properties

\begin{tabular}{|c|c|c|c|c|c|c|c|c|c|c|}
\hline & Diameter & $\begin{array}{l}\text { Water } \\
\text { depth }\end{array}$ & $\begin{array}{l}\text { Head } \\
\text { space }\end{array}$ & $\begin{array}{l}\text { Ice } \\
\text { thickness }\end{array}$ & $\begin{array}{l}\text { Total } \\
\text { depth }\end{array}$ & $\begin{array}{l}\text { Water } \\
\text { volume }\end{array}$ & $\begin{array}{c}\text { Distance along } \\
\text { center }\end{array}$ & Elevation & Slope & $\begin{array}{c}\text { Annual ablation } \\
\text { rate }\end{array}$ \\
\hline $\mathrm{Na}^{+}$ & 0.154 & -0.324 & 0.059 & -0.088 & -0.287 & -0.045 & 0.480 & 0.542 & -0.387 & -0.459 \\
\hline $\mathrm{Ca}^{2+}$ & 0.121 & -0.401 & -0.093 & 0.027 & -0.326 & -0.129 & 0.409 & 0.370 & -0.126 & -0.439 \\
\hline $\mathrm{Mg}^{2+}$ & 0.012 & -0.468 & 0.092 & 0.023 & -0.283 & -0.220 & 0.378 & 0.338 & -0.112 & -0.406 \\
\hline $\mathrm{Cl}^{-}$ & 0.083 & -0.424 & 0.208 & -0.170 & -0.354 & -0.152 & 0.525 & 0.491 & -0.394 & -0.459 \\
\hline
\end{tabular}

NB: Italics show significant correlation with 95\% confidence, bold shows significant correlation with $99 \%$ confidence.

duration' calculation was performed (Eqn (1); Fountain and others, 2004). This analysis was based on the 50 holes sampled in this study. The sampled cryoconite holes did not include holes visibly connected to near-surface channels, as it was difficult to assess the boundaries of these features. Therefore, it is possible that the level of connectivity is higher than estimated from the model results. It should be emphasized that the fraction of holes visibly connected to near-surface channels was very low.

At least $25 \%$ of the measured holes on the planar surface $(n=50)$ were connected to other holes, inter-granular passageways, and/or near-surface conduits (Fig. 3a). As holes that had obvious conduits and cracks were avoided during sampling, the connections are likely intergranular in nature. The computed isolation durations suggest that the average age of water in the holes was $3.5 \mathrm{a}$, and that 37 of the 50 holes sampled were hydrologically isolated, with a maximum age of $18 \mathrm{a}$ at sampling location $\mathrm{E}$. The hole with the highest calculated isolation age had much higher concentrations of both $\mathrm{Na}^{+}$and $\mathrm{Cl}^{-}$than surrounding holes, and also had higher water and total depth than surrounding holes. The percentage of cryoconite holes in this study that were connected was considerably lower than was reported by Fountain and others (2004) for Canada Glacier, McMurdo Dry Valleys, where 56\% of 16 holes sampled were judged to be connected (via surface and near-surface channels; Fountain and others, 2004). However, all holes sampled in this study were expected to be 'isolated', as holes that were obviously connected via conduits and cracks were avoided during sampling. Most of the holes that were found to be connected were located in the terminus regions near sites A and B (Fig. 3a), although three holes at site $\mathrm{H}$ were subsequently judged to be 'connected'. Two-tailed Pearson correlation analyses showed that the calculated cryoconite hole isolation time was significantly positively correlated with water depth $(p<0.01)$ and total depth $(p<0.05)$, but with no other site characteristics (Table 8). Logistic regression showed that the probability of a hole being connected was positively related to elevation $(p<0.01)$, hole diameter $(p<0.05)$ and water depth in the

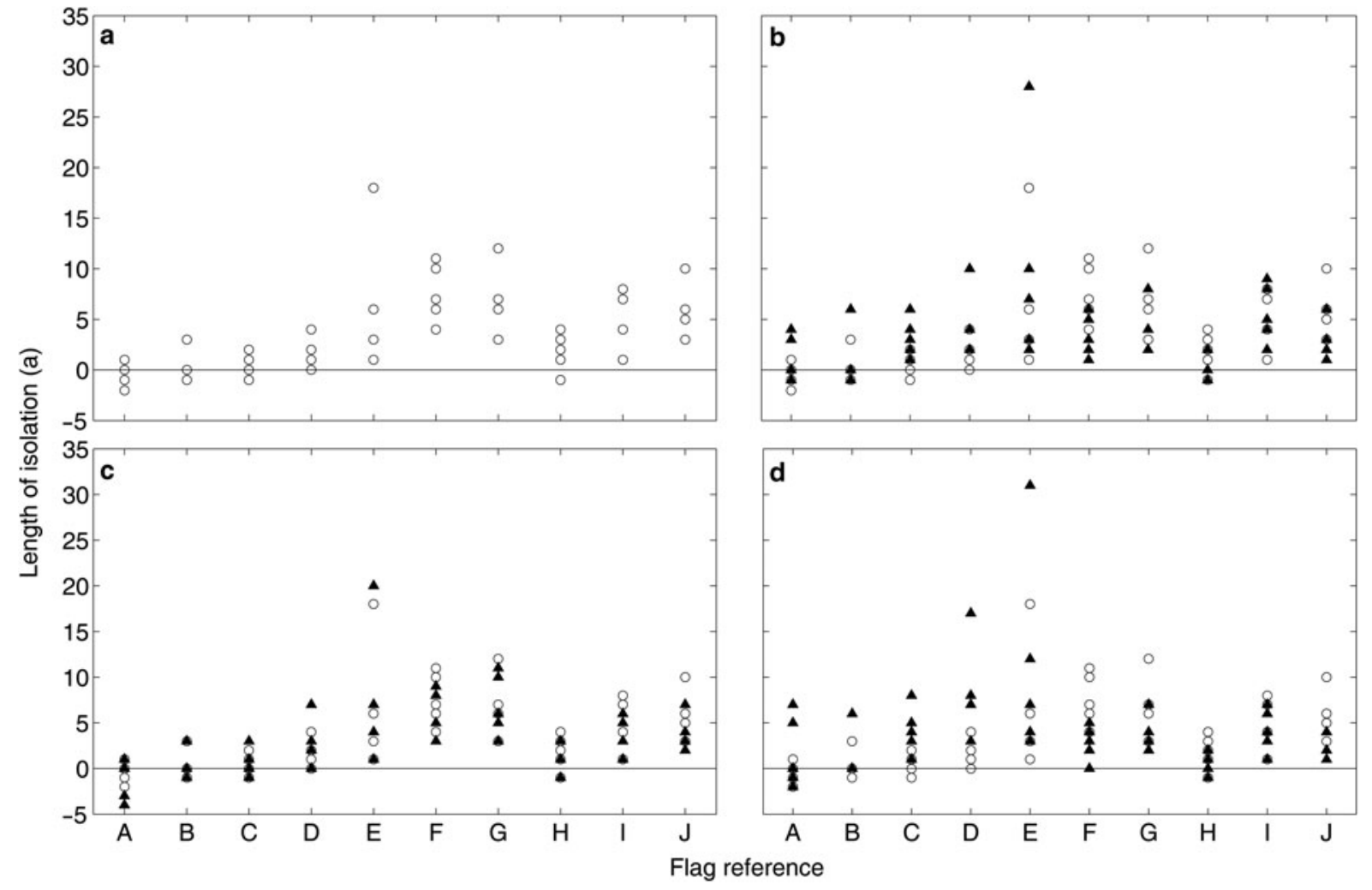

Fig. 3. Length of isolation of cryoconite holes between sites A and J along the glacier centerline using (a) glacier averaged surface ice chloride concentrations and ablation rate (hollow circles in all figures); (b) site specific chloride concentrations (black triangles); (c) site specific ablation rates (black triangles); and (d) site specific chloride concentrations and ablation rates (black triangles). NB: Each flag site has five measurements and repeated values are plotted overlying one another. 
Table 8. (a) Two-tailed Pearson correlation coefficient results of comparison between isolation duration with hole and site properties. (b) $p$-value results of logistical regression analyses comparing cryoconite hole age and connectivity with hole and site properties

\begin{tabular}{|c|c|c|c|c|c|c|c|c|c|c|}
\hline & Diameter & $\begin{array}{l}\text { Water } \\
\text { depth }\end{array}$ & $\begin{array}{l}\text { Head } \\
\text { space }\end{array}$ & $\begin{array}{c}\text { Ice } \\
\text { thickness }\end{array}$ & $\begin{array}{l}\text { Total } \\
\text { depth }\end{array}$ & $\begin{array}{l}\text { Water } \\
\text { volume }\end{array}$ & $\begin{array}{c}\text { Distance along } \\
\text { center }\end{array}$ & Elevation & Slope & $\begin{array}{c}\text { Annual ablation } \\
\text { rate }\end{array}$ \\
\hline (a) & 0.042 & 0.369 & -0.132 & 0.117 & 0.308 & 0.110 & 0.081 & 0.121 & -0.269 & -0.128 \\
\hline (b) & 0.032 & 0.040 & 0.554 & 0.611 & 0.398 & 0.063 & 0.023 & 0.010 & 0.002 & 0.351 \\
\hline
\end{tabular}

NB: Italics show significant correlation with 95\% confidence, bold shows significant correlation with $99 \%$ confidence.

hole $(p<0.05)$, and negatively related to local slope angle $(p<0.01)$ and distance from the terminus $(p<0.05)$.

The increased connectivity of cryoconite holes near the glacier terminus may be due to higher air temperatures enabling higher rates of melt and inter-granular flow, and to inputs of water from upstream. Holes near the terminus are likely to be more transient, and hence more shortlived, due to the higher likelihood of surface stripping melt events at lower elevations caused by relatively high air temperatures (Fountain and others, 2004; MacDonell and Fitzsimons, 2012). However, as inter-granular drainage was observed across the glacier surface, it is difficult to determine what causes a cryoconite hole to be identified as 'isolated' or 'connected', as any hole experiencing inter-granular drainage is by definition 'connected'. It seems likely that Eqn (1) does not give a binary 'connected' or 'isolated' signal, but rather a relative measure of connectedness to the drainage system. To confirm these results, the use of Eqn (1) is tested for model sensitivity to ice chloride concentrations, and the spatial variability of surface ablation rates.

\subsection{Sensitivity analysis of the cryoconite hole isolation duration calculation}

Two assumptions that have been used in previous calculations of cryoconite hole isolation duration on McMurdo Dry Valleys glaciers are (1) that the chloride concentration of the ice surrounding the holes is uniform across the glacier surface, and (2) that the surface lowering rate is spatially uniform (Fountain and others, 2004; Bagshaw and others, 2007).

To test whether incorporating the spatial variability of chloride concentrations in surface ice into the isolation duration calculation significantly alters the final results, cryoconite hole isolation calculations were performed using (1) an area-average chloride concentration $\left(19.7 \mu \mathrm{eq} \mathrm{L}^{-1}\right)$, and (2) the chloride concentration from the nearest surface ice sample (Fig. 3b; Table 4). The choice of which surface ice $\mathrm{Cl}^{-}$concentration to use in the isolation duration calculation results in a variation of up to $10 \mathrm{a}$ in the isolation age of an individual cryoconite hole in the most extreme case. Incorporating the spatial variation of surface ice chloride concentrations generally yielded lower isolation durations for sites site $F$, and higher isolation durations below F. From this calculation, it is clear that the natural variability in $\mathrm{Cl}^{-}$ is sufficiently large that the choice of $\mathrm{Cl}^{-}$value has a significant influence on the results.

The second set of assumptions used in previous studies is that the surface lowering rate is constant across the glacier surface, and that the ablation rate at the base of the hole is equal to that of the ice surface surrounding the hole (i.e. that all holes are in a steady state). To test the impact of violating these assumptions, the isolation duration calculation was repeated using both the mean ablation rate $0.11 \mathrm{~m}$ $\mathrm{a}^{-1}$ ) and a site-specific rate calculated from the closest ablation stake (Fig. 3c). This comparison showed that while using different ablation rates did not significantly affect the calculated connectivity status, it did affect the calculated isolation time. The calculation is extremely sensitive to the ablation rate used, such that the lower the ablation rate, the lower the corresponding hole isolation time. This relationship holds because the isolation time is determined from the mass of solute accumulated in the water volume in the hole. This is largely a function of the rate of melting at the base of the hole which, in turn, is assumed to match the surface ablation rate. This has serious implications for calculating the spatial distribution of cryoconite hole ages.

Finally, when both site-specific chloride concentrations and ablation rates are used, the spatial pattern observed in the other results is lost, as holes closer to the terminus appear to be isolated for a longer period than is suggested by the original calculation, while holes away from the terminus have a lower isolation time than in the original calculation (Fig. 3).

\section{DISCUSSION AND CONCLUSIONS}

Observations of both discrete channel connections and intergranular drainage across the glacier surface show that while cryoconite holes on this glacier appear to be mechanically isolated due to the presence of an ice lid, it is likely that in some way all cryoconite holes are hydraulically connected. The level of connectivity is temporally unstable, in so far as holes may disconnect and reconnect seasonally or multiseasonally. The mechanisms of connection, and associated temporal variability, have implications for biogeochemical cycling, and hence the transport of nutrients and biological material across the glacier surface and to proglacial areas. It is likely that patterns of solute concentrations measured across the glacier surface are indicative not only of source material, but also of hydraulic connectivity.

Several studies investigating the role of cryoconite holes in the surface hydrology of glaciers in the McMurdo Dry Valleys have used $\mathrm{Cl}^{-}$concentrations in cryoconite hole waters to determine the level of connectivity between cryoconite holes and the wider glacier drainage system (e.g. Fountain and others, 2004; Bagshaw and others, 2007). While the chloride isolation aging technique is novel and relatively easy to apply, the method has limitations that remain largely unaddressed in the literature. Two main issues are that (1) the method has not been independently validated, so there is no real basis for confidence in the results it produces and (2) there is significant spatial variability in the values of the key parameters used in the calculation, which tends to suggest a more general variability in the rate of solute elution from the ice that is related to both local melt 
Table 9. Quantity of $\mathrm{Cl}^{-}$expected in a theoretical cryoconite hole at sampling locations $\mathrm{A}$ and $\mathrm{J}$ calculated from a constant ablation rate of $0.1 \mathrm{~m} \mathrm{a}^{-1}$ and a surface area of $0.5 \mathrm{~m}^{2}$

\begin{tabular}{lcc}
$\begin{array}{l}x \\
\mathrm{a}\end{array}$ & \multicolumn{2}{c}{$\begin{array}{c}\text { Quantity of } \mathrm{Cl}^{-} \text {from } x \text { years melt } \\
\mu \mathrm{mol}\end{array}$} \\
\cline { 2 - 3 } & Site A & Site J \\
\hline 1 & 0.0006 & 0.0015 \\
5 & 0.0028 & 0.0076 \\
10 & 0.0055 & 0.0152 \\
20 & 0.0111 & 0.0303 \\
30 & 0.0166 & 0.0455
\end{tabular}

rates and distance downstream within the ablation area. If cryoconite holes persist for long enough that they are advected down-glacier over time and are thus surrounded by ice with time-varying solute content and subjected to time-varying local surface ablation rates, then the simplistic assumptions on which the isolation calculation is based are highly likely to be violated. The assumption of steady-state holes requires not only that ablation rates at a given location remain constant through time, but also that the incident radiation receipt, the optical and physical properties of the surface ice, and the cryoconite itself, must remain constant (Gribbon, 1979; Fountain and others, 2008). Under this scenario, as holes are multi-year features, single year melt rates may not be a good approximation for the rates cryoconite holes experience in their lifetime.

One of the primary assumptions of using the solute mass accumulated in a cryoconite hole as a proxy for the isolation time of the hole is that solute accumulates in the hole over time as a result of release from melting of the base of the hole. However, in all studies using Eqn (1) to estimate isolation duration (including the current study), an average of surface ice concentrations has been used instead of the concentration at the base of the hole. As shown in Tables 4 and 5 , while there is general agreement between surface and deep ice $\mathrm{Cl}^{-}$values, there is some degree of variation. By inference, it is likely there is some form of concentration profile with depth that is likely to vary across the glacier surface. Therefore, it is likely that the contribution to the hole from surrounding ice actually changes with time. As we currently do not have fine scale measurements of $\mathrm{Cl}^{-}$concentrations it is difficult to estimate what impact this variability may have on the calculated concentration, but it serves to highlight the current unknowns in solute mobility in this environment. In addition, as shown in Table $4 \mathrm{Cl}^{-}$concentrations in surface ice clearly vary over relatively large distances, but we are unsure as to how variable they are over relatively short distances.

Spatial variations in surface ice $\mathrm{Cl}^{-}$concentrations will affect not only the probable initial $\mathrm{Cl}^{-}$concentration of cryoconite hole waters, but also the $\mathrm{Cl}^{-}$concentrations in any water that might travel through the near-surface drainage network. To illustrate the point, Table 9 shows the concentration of $\mathrm{Cl}^{-}$expected in cryoconite holes at sites $\mathrm{A}$ and $\mathrm{J}$, respectively, assuming the hole area $\left(0.5 \mathrm{~m}^{2}\right)$ and ablation rate $\left(0.1 \mathrm{~m} \mathrm{a}^{-1}\right)$ are the same at both locations and constant in time. At A, the surface ice $\mathrm{Cl}^{-}$concentration is $0.01 \mu \mathrm{mol}$ $\mathrm{m}^{-3}$, which represents the lowest concentration of all measured sites (Table 4). By comparison, the surface ice concentration at J (the highest measured stake) $\left(0.03 \mu \mathrm{mol} \mathrm{m}{ }^{-3}\right)$ is the second highest measured. Table 9 shows that the higher surface ice concentration at $\mathrm{J}$ is associated with cryoconite water concentrations almost three times higher than observed at A. If this water is flushed downstream, it will increase concentrations in downstream holes, which will cause an apparent increase in calculated residence time.

The systematic increase in solute concentration in ice with distance from terminus in the ablation area may not reflect differences in distance from the precipitation source, but may reflect a trend to increasing water flow through the ice at lower elevations that results in solute elution from the near-surface ice in which cryoconite holes form. Under this hypothesis, even if the model used to compute the isolation time of a single hole is basically correct, holes of identical ages formed in ice with different initial composition will appear to have different ages if the variations in ice composition are ignored or averaged out.

In the isolation duration calculation, it is assumed that any interaction between the cryoconite hole system and the wider hydrological system resets the hole to age 'zero'. The equation implies that the solute accumulation rate depends on the basal melt rate of the hole and the solute concentration in the ice, and that basal melting occurs at a rate that matches the rate of freezing at the top of the hole and adds solute to the water column. As refreezing at the top of the hole does not remove much solute, because solute is rejected from ice that forms during refreezing, in a steady state, isolated, cryoconite hole, water mass remains constant over time while solute mass (and thus solute concentration) increases. Therefore, the solute concentration in the cryoconite hole waters will generally be higher than in the surrounding ice and in meltwaters derived from melting of that ice. In theory, any flushing of a cryoconite hole that is connected to the near-surface meltwater drainage system will be done by water with a lower solute concentration than the water stored in the hole. This will result in dilution of the hole waters and, since hole volume is assumed not to change over time, which is unlikely, a reduction in the stored solute mass and hence the computed isolation time. However, the addition of water from outside the hole does not necessarily mean that the hole waters are diluted to the point that they no longer contain solute. Thus, at best, the 'isolation age' is really an inverse measure of the rate at which the hole is flushed, and not a true measure of isolation time.

Leading from observations of cryoconite hole connectivity and the development of intergranular drainage on the Wright Lower Glacier (MacDonell and Fitzsimons, 2012), it seems likely that cryoconite holes are never truly isolated from the near-surface drainage system. The nature of the relationship between isolation duration and flushing rate will depend on whether or not the holes really evolve to a steady-state water volume as the model assumes. Both the spatial pattern of $\mathrm{Cl}^{-}$in surface ice, and the computed isolation durations, suggest more flushing of near-surface ice at lower elevations, which is consistent with evidence of a shallow englacial drainage system in this glacier. While this paper has raised some questions about the interpretation of results produced by the isolation model proposed by Fountain and others (2004), it is likely that after independent evaluation of the model assumptions and the extent to which they are consistent with reality, the model may still be useful as a way of identifying large scale spatial patterns in the structure and connectivity of the shallow near-surface drainage system on predominantly cold glaciers. 


\section{ACKNOWLEDGEMENTS}

Financial assistance for S. M. was provided by a University of Otago Postgraduate Scholarship, the Sir Robin Irvine Antarctica New Zealand Doctoral Scholarship and the University of Otago Postgraduate Publishing Bursary. M. S. acknowledges support from the Canadian Arctic-Antarctic Exchange Program (Natural Resources Canada) and an NSERC Discovery Grant. Financial support for S. F. was provided by a University of Otago Research Grant. Logistical support was provided by Antarctica New Zealand. We are grateful for field assistance provided by Lawrence Kees, Laurel Morrison, Dorothea Stumm and Ben Varkalis and to Tracy Connolly for drawing Fig. 1. Fantastic helicopter support was provided by Helicopters NZ pilot Rob McPhail. We are grateful for insightful comments from the two reviewers.

\section{REFERENCES}

Anesio AM, Mindl B, Laybourn-Parry J, Hodson AJ and Sattler B (2007) Viral dynamics in cryoconite holes on a high Arctic glacier (Svalbard). J. Geophys. Res., 112, G04S31 (doi: 10.1029/2006JG000350)

Anesio AM and 6 others (2010) Carbon fluxes through bacterial communities on glacier surfaces. Ann. Glaciol., 51(56), 32-40 (doi: 10.3189/172756411795932092)

Bagshaw EA and 5 others (2007) Biogeochemical evolution of cryoconite holes on Canada Glacier, Taylor Valley, Antarctica. J. Geophys. Res., 112, G04S35 (doi: 10.1029/2007JG000442)

Bagshaw EA and 5 others (2013) Do cryoconite holes have the potential to be significant sources of $\mathrm{C}, \mathrm{N}$, and $\mathrm{P}$ to downstream depauperate ecosystems of Taylor Valley, Antarctica? Arct. Antarct. Alp. Res., 45(4), 440-454 (doi: 10.1657/1938-4246-45.4.440)

Brandt RE and Warren SG (1993) Solar-heating rates and temperature profiles in Antarctic snow and ice. J. Glaciol., 39(131), 99110 (doi: 10.3198/1993JoG39-131-99-110)

Cragin JH and McGilvary R (1995) Can inorganic species volatize from snow? In Tonnessen KA, Williams MW and Tranter M ed. Biogeochemistry of Seasonally Snow-Covered Catchments, IAHS Publication No 228, Wallingford, UK, 11-16

Cook JM, Hodson AJ and Irvine-Fynn TDL (2016) Supraglacial weathering crust dynamics inferred from cryoconite hole hydrology. Hydrol. Process., 30(3), 433-446 (doi: 10.1002/hyp.10602)

Domine F, Sparapani R, lanniello A and Beine HJ (2004) The origin of sea salt in snow on Arctic sea ice and in coastal regions. Atmos. Chem. Phys., 4, 2259-2271 (doi: 10.5194/acp-4-22592004)

Doran PT and 6 others (2002) Valley floor climate observations from the McMurdo dry valleys, Antarctica, 1986-2000. J. Geophys. Res., 107(D24), 4772 (doi: 10.1029/2001JD002045)

Douglas TA and 11 others (2012) Frost flowers growing in the Arctic ocean-atmosphere-sea ice-snow interface: 1. Chemical composition. J. Geophys. Res., 117, D00R09 (doi: 10.1029/ 2011JD016460)

Edwards A and 7 others (2011) Possible interactions between bacterial diversity, microbial activity and supraglacial hydrology of cryoconite holes in Svalbard. ISME J., 51(1), 150-160 (doi: 10.1038/ismej.2010.100)

Fitzsimons SJ and 5 others (2008) Mechanisms of basal ice formation in polar glaciers: an evaluation of the apron entrainment model. J. Geophys. Res., 113, F02010 (doi: 10.1029/2006JF000698)

Foreman CM, Wolf CF and Priscu JC (2004) Impact of episodic warming events on the physical, chemical and biological relationships of lakes in the McMurdo Dry Valleys, Antarctica. Aquat. Geochem., 10(3), 239-268 (doi: 10.1007/s10498-0042261-3)

Fortner SK, Tranter M, Fountain A, Lyons WB and Welch KA (2005) The geochemistry of supraglacial streams of Canada Glacier,
Taylor Valley (Antarctica) and their evolution into proglacial waters. Aquat. Geochem., 11, 391-412 (doi: 10.1007/s10498004-7373-2)

Fountain AG, Tranter M, Nylen TH, Lewis KJ and Mueller DR (2004) Evolution of cryoconite holes and their contribution to meltwater runoff from glaciers in the McMurdo Dry Valleys, Antarctica. J. Glaciol., 50(168), 35-45 (doi: 10.3189/ 172756504781830312)

Fountain AG, Nylen TH, Tranter M and Bagshaw E (2008) Temporal variations in physical and chemical features of cryoconite holes on Canada Glacier, McMurdo Dry Valleys, Antarctica. J. Geophys. Res., 113, G01S92 (doi: 10.1029/2007JG000430)

Fountain AG, Nylen TH, Monaghan A, Basagic HJ and Bromwich D (2010) Snow in the McMurdo Dry Valleys, Antarctica. Int. J. Climatol. 30, 633-642 (doi: 10.1002/joc.1933)

Ginot P, Kull C, Schwikowski M, Schotterer U and Gäggeler HW (2001) Effects of postdepositional processes on snow composition of a subtropical glacier (Cerro Tapado, Chilean Andes). J. Geophys. Res., 106(D23), 32375-32386 (doi: 10.1029/ 2000JD000071)

Gooseff MN, McKnight DM and Runkel RL (2004) Reach-scale cation exchange controls on major ion chemistry of an Antarctic glacial meltwater stream. Aquat. Geochem., 10, 221238 (doi: 10.1007/s10498-004-2260-4)

Gribbon PW (1979) Cryoconite holes on Sermikaysak, West Greenland. J. Glaciol., 22, 177-181

Hodson AJ and 7 others (2008) Glacial ecosystems. Ecol. Monogr., 78, 41-67 (doi: 10.1890/07-0187.1)

Hoffman MJ, Fountain AG and Liston GE (2014) Near-surface internal melting: a substantial mass loss on Antarctic Dry Valley glaciers. J. Glaciol., 60(220), 361-374 (doi: 10.3189/ 2014JoG13J095)

Irvine-Fynn TDL and 7 others (2012) Microbial cell budgets of an Arctic glacier surface quantified using flow cytometry. Environ. Microbiol., 14(11), 2998-3012 (doi: 10.1111/j.1462-2920. 2012.02876.x)

Keene WC, Pszenny AAAP, Galloway JN and Hawley ME (1986) Sea-salt corrections and interpretation of constituent ratios in marine precipitation. J. Geophys. Res., 91(D6), 6647-6658 (doi: 10.1029/JD091iD06p06647)

Kroopnick P (1977) The SO4:Cl ratio in oceanic rainwater. Pac. Sci., 31(1), 91-106

Lyons WB and 5 others (2003) Surface glaciochemistry of Taylor Valley, southern Victoria Land, Antarctica and its relationship to stream chemistry. Hydrol. Process., 17(1), 115-130 (doi: 10.1002/hyp.1205)

MacDonell S and Fitzsimons S (2008) The formation and hydrological significance of cryoconite holes. Prog. Phys. Geog., 32(6), 595-610 (doi: 10.1177/0309133308101382)

MacDonell S and Fitzsimons S (2012) Observations of cryoconite hole system processes on an Antarctic glacier, and implications for the wider glacier ecosystem. Rev. Chil. Hist. Nat., 85, 393407 (doi: 10.4067/S0716-078X2012000400003)

MacDonell S, Fitzsimons S and Mölg T (2013) Seasonal sediment fluxes forcing supraglacial melting on the Wright Lower Glacier, McMurdo Dry Valleys, Antarctica. Hydrol. Process., 27(22), 3192-3207 (doi: 10.1002/hyp.9444)

Säwström C, Mumford P, Marshall W, Hodson A and LaybournParry J (2002) The microbial communities and primary productivity of cryoconite holes in an Arctic glacier (Svalbard 79 degrees N). Polar Biol., 25, 591-596 (doi: 10.1007/s00300-002-0388-5)

Takeuchi N (2002) Optical characteristics of cryoconite surface dust on glaciers: the relationship between light absorbency and the property of organic matter contained in the cryoconite. Ann. Glaciol., 34, 409-414 (doi: 10.3189/172756402781817743)

Tranter M and 6 others (2004) Extreme hydrochemical conditions in natural microcosms entombed within Antarctic ice. Hydrol. Process., 18(2), 379-387 (doi: 10.1002/hyp.5217)

Tranter M, Fountain AG, Lyons WB, Nylen TH and Welch KA (2005) The chemical composition of runoff from Canada Glacier, 
Antarctica: implications for glacier hydrology during a cool summer. Ann. Glaciol., 40, 15-19 (doi: 10.3189/ 172756405781813753)

Wakahama G and 6 others (1973) Observations of permeating water through a glacier body, Low Temp. Sci., 31A, 209-220

Wharton RA, McKay CP, Simmons GM and Parker BC (1985) Cryoconite holes on glaciers. Bioscience, 35(8), 499-503
Witherow RA and 8 others (2006) The Aeolian flux of calcium chloride and nitrate to the McMurdo Dry Valleys landscape: evidence from snow pit analysis. Antarct. Sci., 18(4), 497-505 (doi: 10.1017/S095410200600054X)

Wolff EW, Rankin AM and Röthlisberger R (2003) An ice core indicator of Antarctic sea ice production? Geophys. Res. Lett., 30(22), 2158 (doi: 10.1029/2003GL018454)

MS received 9 October 2015 and accepted in revised form 26 March 2016; first published online 10 May 2016 